\title{
PENGEMBANGAN LEMBAR KERJA SISWA BERBASIS INKURI UNTUK MENINGKATKAN HOTS SISWA SMA PADA MATERI TRIGONOMETRI
}

\author{
Gida Kadarisma ${ }^{1}$, Indah Puspita Sari², Eka Senjayawati ${ }^{3}$ \\ 1,2,3 IKIP Siliwangi, Jl. Terusan Jendral Sudirman, Indonesia \\ Email: gidakadarisma@gmail.com
}

\begin{abstract}
This research is based on the low High Order Thinking Skills (HOTS) of high school students of one of the private schools in Cimahi on trigonometric materials. Students find it difficult to understand trigonometric materials because the teaching materials used have not facilitated the high-level thinking process of students, so it is necessary to develop inquiry-based teaching materials for the student's HOTS to increase. The purpose of this research is to develop inquirybased LKS in trigonometric materials. The research method uses $4 \mathrm{D}$ design development methods, namely define, design, develop, and disseminate. However, due to time constraints, this research is only up to the development stage. The subject of this study was x-grade students at one of the private high schools in Cimahi City as many as 32 students. Data collection techniques use HOTS test instruments to measure the effectiveness of teaching materials, and validation sheets to measure the validity of teaching materials. Based on the results of data analysis can be concluded that teaching materials in the form of LKS developed are declared valid with the average validity value of the expert validator of 3.4 and the effectiveness of hots capability increase by $35.3 \%$. This study implies that teachers can use this inquirybased LKS as teaching material in trigonometric materials to improve students' HOTS abilities.
\end{abstract}

Keywords: High order thinking skills, inquiry approach, student worksheets

\begin{abstract}
ABSTRAK
Penelitian ini dilatarbelakangi oleh rendahnya High Order Thinking Skills (HOTS) siswa SMA salah satu sekolah swasta di Cimahi pada materi trigonometri. Siswa merasa kesulitan dalam memahami materi trigonometri dikarenakan bahan ajar yang digunakan belum memfasilitasi proses berpikir tingkat tinggi siswa, sehingga diperlukan pengembangan bahan ajar yang berbasis inkuiri agar HOTS siswa semakin meningkat. Tujuan dari peneitian ini untuk mengembangkan LKS berbasis inkuiri pada materi trigonometri. Metode penelitian menggunakan metode pengembangan desain 4D, yaitu pendefinisian (define), perancangan (design), pengembangan (develop), dan penyebaran (disseminate). Namun, karena keterbatasan waktu maka penelitian ini hanya sampai tahap pengembangan. Subjek penelitian ini yaitu siswa kelas $X$ pada salah satu SMA swasta di Kota Cimahi sebanyak 32 siswa. Teknik pengumpulan data menggunakan instrumen tes HOTS untuk mengukur efektivitas bahan ajar, dan lembar validasi untuk mengukur validitas bahan ajar. Berdasarkan hasil analisis data dapat disimpulkan bahwa bahan ajar berupa LKS yang dikembangkan dinyatakan valid dengan ratarata nilai validitas dari validator ahli sebesar 3,4 serta efektivitas dari peningkatan kemampuan HOTS sebesar $35,3 \%$. Adapun implikasi dari penelitian ini yaitu guru dapat menggunakan LKS berbasis inkuiri ini sebagai bahan ajar pada materi trigonometri agar kemampuan HOTS siswa meningkat.
\end{abstract}

Kata kunci: High order thinking skills, lembar kerja siswa, pendekatan inkuiri

Dikirim: 28 Juli 2020; Diterima: 26 Agustus 2020; Dipublikasikan: 30 September 2020

Cara sitasi: Kadarisma, G., Sari, I. P., \& Senjayawati, E. (2020). Pengembangan lembar kerja siswa berbasis inkuri untuk meningkatkan hots siswa sma pada materi trigonometri. Teorema: Teori dan Riset Matematika, 5(2), 239-248. 


\section{PENDAHULUAN}

Matematika adalah ilmu yang abstrak, logis dan merupakan pelayan ilmu (Perdani \& Azka, 2019). Matematika mempunyai peranan penting dalam kehidupan sehari-hari (Yenni \& Sukmawati, 2019). Namun pentingnya matematika tidak dibarengi dengan minat yang baik dari siswa. Siswa cenderung menganggap matematika sesuatu yang menakutkan, sulit dan membosankan (Dila \& Zanthy, 2020). Saat siswa tidak berminat dalam belajar matematika, maka tujuan pembelajaran tidak akan tercapai. Salah satu tujuan dalam belajar matematika adalah agar siswa memiliki kemampuan berpikir tingkat tinggi atau High Order Thinking Skills (HOTS).

HOTS merupakan suatu proses berpikir peserta didik dalam level kognitif yang lebih tinggi yang dikembangkan dari berbagai konsep dan metode kognitif dan taksonomi pembelajaran seperti metode problem solving, taksonomi bloom, dan taksonomi pembelajaran, pengajaran, dan penilaian (Saputra, 2016). High Order Thinking Skill terjadi saat siswa dapat terlibat langsung dengan apa yang mereka ketahui sedemikian rupa untuk mengubahnya, artinya peserta didik dapat mengubah dan mengkreasi pengetahuan yang mereka miliki serta kemudian menghasilkan sesuatu yang baru (Dinni, 2018). Dalam menyelesaikan masalah, diperlukan kemampuan untuk membuat suatu prediksi, perencanaan, pemantauan dan evaluasi pada proses penyelesaian masalah (Zakiah, 2016). Bagi sebagian besar siswa, sesuatu dikatakan masalah apabila situasinya baru (masalah non-rutin) (Fatimah \& Zakiah, 2018). Untuk menyelesaikan masalah non-rutin siswa memerlukan kemampuan berpikir kritis dan kreatif yang keduanya merupakan kemampuan dalam HOTS. Oleh karena itu HOTS sangat penting untuk dikembangkan dalam pembelajaran matematika (Kadarisma, 2016; Sariningsih \& Kadarisma, 2017; Susanto \& Retnawati, 2016) .

Karakteristik dalam soal HOTS meliputi soal yang sifatnya kompleks, mempunyai solusi yang banyak, non algoritmik, mempunyai kriteria yang banyak, memerlukan banyak usaha, serta pengambilan keputusan yang bervariasi (Resnick, 1987). Sedangkan berdasarkan domain Taksonomi Bloom, yang termasuk HOTS yaitu menganalisis, mengevaluasi dan mencipta (Anderson \& Krathwohl., 2015). Dalam menganalisis suatu permasalahan diperlukan pemikiran yang mendalam serta fokus yang baik, begitupun dalam mengevaluasi hasil pekerjaan sendiri (self assesment) harus memiliki kecakapan dan pemikiran yang matang.

Pentingnya HOTS tidak dibarengi dengan kenyataan di lapangan, penelitian menyatakan bahwa HOTS siswa masih tergolong rendah. Kenyataan dari hasil TIMSS 2015 bahwa rata-rata skor yang diperoleh Indonesia berada di bawah rata-rata skor internasional yaitu sebesar 500 dengan memperoleh peringkat 44 dari 49 negara (Hadi \& Novaliyosi, 2019). Selain itu dari hasil studi pendahuluan, setelah memberikan soal HOTS pada siswa kelas IX di salah satu SMA di Kota Bandung hanya $24 \%$ yang dapat menyelesaikannya dengan benar. Kesulitan paling banyak yaitu siswa banyak mengalami lupa rumus dikarenakan pembelajaran yang cenderung prosedural. Berdasarkan hasil observasi rendahnya HOTS ini dikarenakan siswa tidak terbiasa dengan soal HOTS serta bahan ajar yang digunakan guru masih belum bisa melatih HOTS siswa. LKS yang digunakan belum dapat memfasilitasi proses berpikir tingkat tinggi siswa. Oleh karena itu, agar tujuan pembelajaran tercapai secara efektif dan efisien maka guru perlu memiliki kemampuan profesional dalam menyusun bahan ajar (Ahmadi \& Kadarisma, 2020; Fitriani et al., 2020; Kadarisma et al., 2019).

Dari pemaparan-pemaparan permasalahan di atas, dibutuhkan suatu bahan ajar yang dapat meningkatkan HOTS siswa dalam pembelajaran matematika. Bahan ajar atau perangkat pembelajaran yang dimaksud adalah Lembar Kerja Siswa (LKS) berbasis inkuiri. LKS merupakan salah satu alternatif yang sering digunakan dalam proses pembelajaran matematika, penyusunan dan penggunaan LKS yang tepat dapat membantu peserta didik dalam mengembangkan HOTS (Kristianingsih \& Wijayati, 2016; Musfiqi \& Jailani, 2014; Utari et al., 2017; Wardhani et al., 2017). Sayangnya banyak LKS yang digunakan tidak memperhatikan aspek HOTS yang harus dikembangkan siswa. Oleh karena itu peneliti memberikan solusi dengan menggunakan LKS berbasis inkuiri. Tahapan pada inkuiri yaitu merumuskan masalah, menentukan hipotesis, mengumpulkan data, menarik kesimpulan serta melakukan generalisasi (Sudjana, 2008). Melalui tahap-tahap tersebut jenis LKS ini dapat membantu siswa menumbuhkembangkan HOTS 
karena membuat siswa lebih banyak belajar sendiri dan mengembangkan kekreatifan dalam memecahkan masalah (Ahmatika, 2017). Hal ini sejalan dengan hasil penelitian terdahulu menyatakan LKS berbasis inquiry akan meningkatkan kemampuan berpikir tingkat tinggi siswa (Ahmatika, 2017; Mulbasari, 2016; Wardhani et al., 2017) .

Penelitian mengenai pendekatan inkuiri dalam pembelajaran matematika telah banyak dilakukan. Salah satunya penelitian yang dilakukan Tjiptiany et al. (2016) mengembangkan bahan ajar berbasis inkuiri pada materi peluang. Berdasarkan hasil penelitian bahan ajar yang dikembangkan diperoleh hasil valid, praktis, serta efektif digunakan, dan dapat melatih kemandirian siswa dalam mengerjakan soal. Penelitian lain dilakukan oleh Jusniani (2016) yang meneliti pendekatan inkuiri dalam meningkatkan kemampuan berpikir kritis siswa melalui PTK, hasil dari penelitian ini menunjukkan kemampuan berpikir kritis siswa meningkat dengan pembelajaran inkuiri. Tujuan penelitian ini adalah untuk mengembangkan bahan ajar berupa LKS berbasis inkuiri yang dapat meningkatkan HOTS siswa. Pada penelitian ini akan dianalisis bagaimana pengembangan bahan ajar inkuiri dalam meningkatkan HOTS pada materi trigonometri. Materi trigonometri dipilih karena trigonometri merupakan salah satu materi yang sulit dikuasai siswa, selain itu trigonometri sangat diperlukan dalam kehidupan sehari-hari (Mahendratama, 2019). Melalui penguasaan konsep awal trigonometri dari bahan ajar, proses berpikir siswa akan lebih difasilitasi. Oleh karena itu pengembangan bahan ajar menggunakan inkuiri pada materi trigonometri ini penting dilakukan, sehingga diharapkan HOTS siswa dapat meningkat.

\section{METODE PENELITIAN}

Penelitian ini menggunakan metode penelitian pengembangan R\&D dengan desain $4 D$ yaitu define (pendefinisian), design (perancangan), develop (pengembangan), dan dissemination (penyebaran). Pada tahap pendefinisian dilakukan analisis kurikulum berupa peninjauan RPP dengan menganalisis standar kompetensi dan kompetensi dasar serta indikator tujuan pembelajaran. Pada tahap ini dilakukan pula analisis LKS yang digunakan siswa serta wawancara pada siswa kelas XI yang telah mempelajari materi trigonometri mengenai kesulitan dalam mempelajari trigonometri. Pada tahap perencanaan dilakukan penyusunan instrumen soal pada materi trigonometri untuk mengukur tingkat HOTS siswa. Soal yang disusun memuat indikator HOTS kemampuan berpikir kritis, kreatif, pemecahan masalah serta membuat keputusan sebanyak 4 butir soal uraian, yang terlebih dahulu diuji validitas serta reliabilitasnya.

Pada tahap pengembangan, dilakukan penyusunan LKS berbasis inkuiri. LKS ini disusun berdasarkan kesulitan siswa dalam mengerjakan tes HOTS pada saat studi pendahuluan serta memperhatikan aspek kebutuhan siswa, yang kemudian diberikan kepada expert untuk divalidasi. Validator sebanyak 3 orang yang tediri dari 2 orang validator konten dan satu orang guru. Setelah itu dilakukan uji coba LKS kepada siswa. Penelitian ini tidak sampai tahap penyebaran. Subyek dari penelitian ini adalah Kelas X pada salah satu SMA swasta di Kota Cimahi sebanyak 32 siswa yang telah dipilih secara acak.

Teknis analisis data yaitu dengan mengukur validitas serta keefektifan LKS setelah dilakukan uji coba. Adapun validitas yang diukur meliputi validitas isi, validitas konstruk serta validitas muka. Masingmasing validator diberikan angket validasi LKS sebanyak 12 pernyataan dengan rentang 1-4. Kemudian dihitung rata-rata skor validitas dari tiap validator. Adapun kriteria validitas merujuk pada Tabel 1.

Tabel 1. Kriteria validitas

\begin{tabular}{ccc}
\hline Skor rata-rata validitas & Kriteria & Interpretasi \\
\hline $3<\mathrm{V} \leq 4$ & Valid & Tidak revisi \\
$2<\mathrm{V} \leq 3$ & Cukup valid & Revisi \\
$1<\mathrm{V} \leq 2$ & Kurang valid & Revisi \\
$\mathrm{V} \leq 1$ & Tidak valid & Revisi
\end{tabular}

Selanjutnya, untuk menganalisis keefektivan LKS yaitu dengan melihat peningkatan hasil tes HOTS awal dengan hasil tes HOTS akhir yang dilakukan setelah uji coba LKS. Kriterianya tersaji dalam Tabel 2. 
Tabel 2. Kriteria efektivitas

\begin{tabular}{cc}
\hline Rata-rata \% peningkatan & Kriteria efektivitas \\
\hline $\mathrm{E}>50 \%$ & Efektivitas sangat tinggi \\
$30 \%<\mathrm{E} \leq 50 \%$ & Efektivitas tinggi \\
$10 \%<\mathrm{E} \leq 30 \%$ & Efektivitas cukup \\
$\mathrm{E} \leq 10 \%$ & Efektivitas kurang \\
\hline
\end{tabular}

\section{HASIL DAN PEMBAHASAN}

Penelitian ini merupakan penelitian pengembangan dengan menggunakan desain $4 D$, namun karena keterbatasan waktu tidak dilakukan tahap penyebaran. Berikut ini akan dibahas tahapan dari 4D yang telah dilakukan:

1. Tahap Pendefinisian

Pada tahapan ini dilakukan tes untuk studi pendahuluan pada siswa kelas XI yang telah mendapatkan materi trigonometri di kelas $X$. Setelah itu dilakukan wawancara tidak terstruktur pada siswa kelas XI mengenai kesulitan dalam mempelajari trigonometri, dari 8 siswa menyatakan merasa kesulitan dalam memahami trigonometri karena harus banyak menghafal rumus. Seperti rumus selisih atau jumlah dua sudut, mereka kesulitan saat ujian karena tidak dapat melihat catatan untuk melihat rumus. Hasil wawancara lainnya menemukan sisa kesulitan dalam memahami konsep awal yaitu perbandingan trigonometri sudut siku-siku. Mereka hanya mengandalkan hafalan rumus saja, sehingga saat segitiga dibuat dalam representasi lain mereka kebingungan, Padahal konsep dasar tersebut menjadi pondasi untuk memahami materi trigonometri lanjut. Temuan lain dari hasil wawancara adalah siswa merasa kesulitan dalam membuat grafik fungsi trigonometri. Hal ini dikarenakan pemahaman mengenai konsep fungsi dan sudut berelasi masih sangat kurang. Selanjutnya dilakukan analisis bahan ajar yang digunakan oleh guru sebelumnya. Buku ajar menggunakan buku yang sudah disediakan pemerintah. Dari beberapa latihan soal dirasa kurang dapat meningkatkan HOTS siswa, seperti terlihat pada Gambar 1.

\section{Contoh 8.1}

Perhatikan jenis ukuran sudut berikut ini, dan ubahlah.

1. $\frac{1}{5} \pi \mathrm{rad}=\ldots$ putaran $=\ldots$ 。

$2 \frac{1}{6}$ putaran $=\ldots \mathrm{rad}=\ldots{ }^{\circ}$

3. $135^{\circ}=\ldots \mathrm{rad}=\ldots$ putaran

4. Sudut yang dibentuk jarum jam, saat pukul 14.40, sama dengan berapa radian?

5. Jika suatu alat pemancar berputar 60 putaran dalam setiap menit, berapa besar putaran dalam derajat per detik? Berapa putaran dalam radian per detik?

Gambar 1. LKS yang biasa digunakan guru

Proses selanjutnya yaitu menganalisis Kompetensi Dasar pada materi trigonometri. Terdapat tujuh kompetensi dasar, beberapa diantaranya yaitu memahami konsep perbandingan trigonometri pada segitiga siku-siku, menemukan sifat-sifat dan hubungan antar perbandingan trigonometri, menentukan hubungan perbandingan trigonometri dari tiap kuadran, memahami konsep fungsi trigonometri, dan menganalisis grafik fungsinya. Materi prasyarat untuk mempelajari trigonometri yaitu materi segitiga. Agar pemahaman lebih mendalam, materi segitiga siku-siku harus dikuasai siswa terlebih dahulu. Guru hendaknya mengecek pemahaman siswa mengenai segitiga siku-siku sebelum mempelajari trigonometri.

\section{Tahap Perencanaan}

Pada tahap perencanaan, dilakukan penyusunan soal HOTS pada materi trigonometri. Instrumen ini dibuat untuk menganalisis keefektivan LKS yang disusun. Indikator soal HOTS mencakup kemampuan berpikir kritis, kreatif, pemecahan masalah, serta membuat keputusan sebanyak 4 butir soal uraian. Instrumen soal sebelumnya diuji coba untuk dianalisis validitas serta reliabilitasnya. Setelah soal dinyatakan valid dan reliabel kemudian soal diuji coba kepada siswa kelas XI sebanyak 32 siswa. Hasil analisis data disajikan pada Tabel 3 . 
Tabel 3. Rekapitulasi hasil tes hots awal

\begin{tabular}{lccc}
\multicolumn{1}{c}{ Aspek yang diukur } & SMI & $\overline{\boldsymbol{x}}$ & $\begin{array}{c}\text { \% Ketercapaian } \\
\text { indikator }\end{array}$ \\
\hline Berpikir kritis & 25 & 7,2 & $28,8 \%$ \\
Berpikir kreatif & 25 & 6,4 & $25,6 \%$ \\
Pemecahan masalah & 25 & 10,5 & $42 \%$ \\
Membuat keputusan & 25 & 7,8 & $31,2 \%$ \\
Rata-rata & & 7,95 & $31,9 \%$ \\
\hline
\end{tabular}

Berdasarkan Tabel 3 terlihat dari SMI masing-masing aspek sebesar 25 hanya mencapai rata-rata 7,95 atau persentase ketercapaian sebesar 31,9\%. Aspek paling rendah sebesar 6,4 yaitu pada berpikir kreatif. Hal ini menunjukkan bahwa HOTS siswa tergolong rendah, dengan demikian diperlukan penyusunan bahan ajar dengan pendekatan yang dapat menumbuhkembangkan HOTS siswa yaitu dengan LKS berbasis inkuiri. Dari hasil tes awal, kemudian dilanjutkan dengan tahap pengembangan.

\section{Tahap Pengembangan}

Pada tahap ini dilakukan pengembangan LKS berbasis inkuiri yang disusun berdasarkan kebutuhan siswa serta analisis bahan ajar yag digunakan sebelumnya. Langkah-langkah yang dilaksanakan dari tahap pengembangan ini yaitu menentukan kompetensi dasar, menentukan indikator pembelajaran, menyusun bahan ajar berupa LKS, membuat cover LKS yang sesuai dengan tema materi, kemudian LKS yang telah disusun divalidasi oleh 3 orang validator ahli, setelah itu dilakukan ujicoba terbatas kepada satu kelas untuk meihat apakah LKS yang digunakan efektif atau tidak. Urutan materi dari LKS yang telah dikembangkan yaitu: pengukuran sudut, perbandingan trigonometri pada segitiga siku-siku, nilai perbandingan trigonometri untuk sudut istmewa, sudut relasi trigonometri, identitas trigonometri, serta fungsi trigonometri. Berikut tampilan bahan ajar yang telah dikembangkan seperti pada Gambar 2.

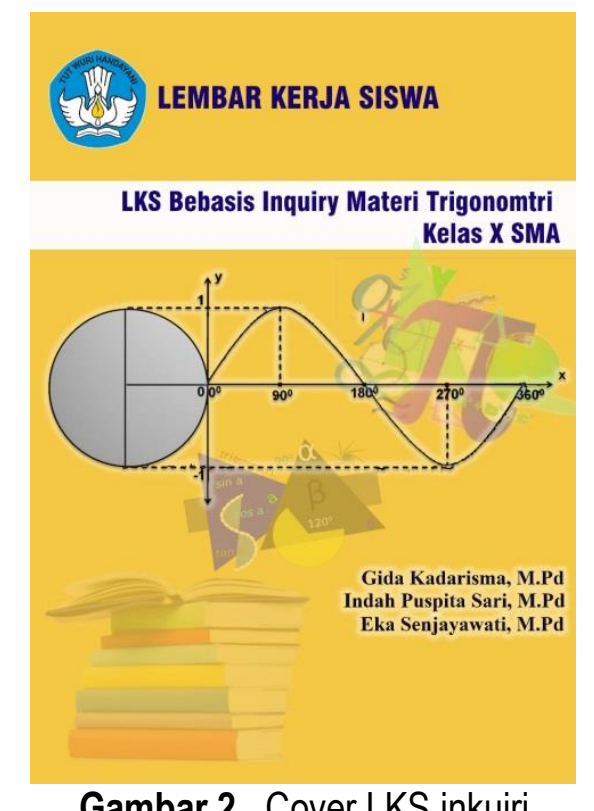

LKS divalidasi oleh 3 orang validator ahli yang terdiri dari 1 guru mata pelajaran matematika sebagai praktisi, serta 2 validator ahli pakar pendidikan matematika. Ketiga validator diberikan lembar validasi untuk mengukur validitas isi, validitas konstruk, dan validitas muka yang dimuat dalam 12 pernyataan dengan rentang 1-4. Hasil rekapitulasi penilaian expert disajikan pada Tabel 4. 
Tabel 4. Rekapitulasi hasil validasi

\begin{tabular}{lcccc}
\hline Aspek yang diukur & Validator $\mathbf{1}$ & Validator $\mathbf{2}$ & Validator $\mathbf{3}$ & Rata-rata \\
\hline Validitas isi & 3 & 3,25 & 3,25 & 3,12 \\
Validitas konstruk & 3,75 & 3 & 3,25 & 3,3 \\
Validitas muka & 3,5 & 3,5 & 3 & 3,3 \\
Rata-rata & 3,42 & 3,25 & 3,12 & 3,24 \\
\hline
\end{tabular}

Pada Tabel 4. Dapat dilihat bahwa rata-rata skor validitas isi sebesar 3,12, validitas konstruk sebesar 3,3 dan validitas muka sebesar 3,3. Setelah dirata-rata skor validasi secara keseluruhan adalah 3,24. Berdasarkan kriteria pada Tabel 1. Maka skor validasi masuk kedalam kriteria "Valid". Adapun komentar dari validator 1 yaitu uji kompetensi yang diberikan dibuat per pokok materi agar dapat memantau pemahaman siswa tiap pokok bahasa. Komentar dari validator 2 yaitu agar pada pembahasan mengenai materi fungsi trigonometri hendaknya siswa diingatkan kembali mengenai fungsi linear. Sedangkan tidak ada komentar untuk validator ke-3. Revisi dilakukan sesuai dengan komentar dari validator ahli. Berikut hasil sebelum dan sesudah revisi dari masukan validator ke-2 disajikan pada Gambar 3 dan Gambar 4.

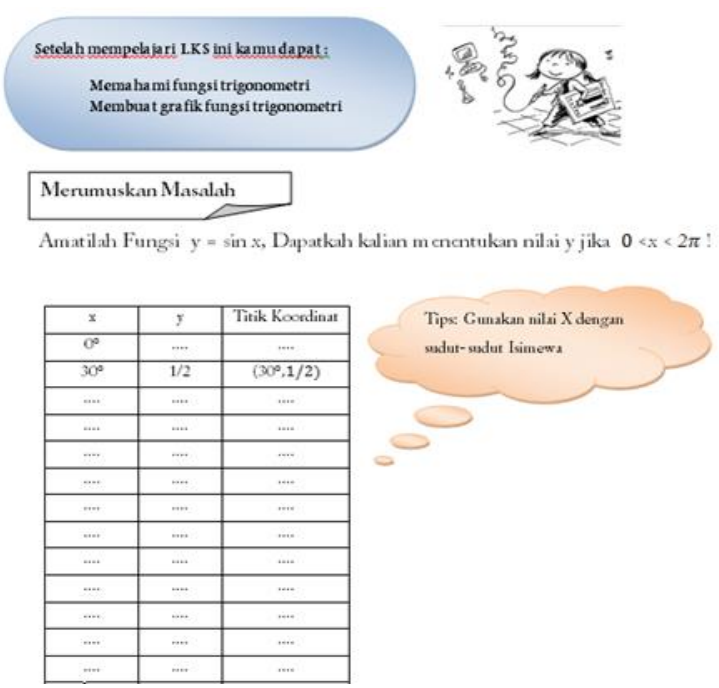

Gambar 3. LKS sebelum revisi

Gambar 3 merupakan salah satu bagian dari isi LKS dengan materi fungsi trigonometri, pada masukan penilaian validator ahli bagian ini diminta untuk ditambahkan stimulus berupa disajikannya materi prasyarat mengenai fungsi linear. Revisi LKS tersaji pada Gambar 4.

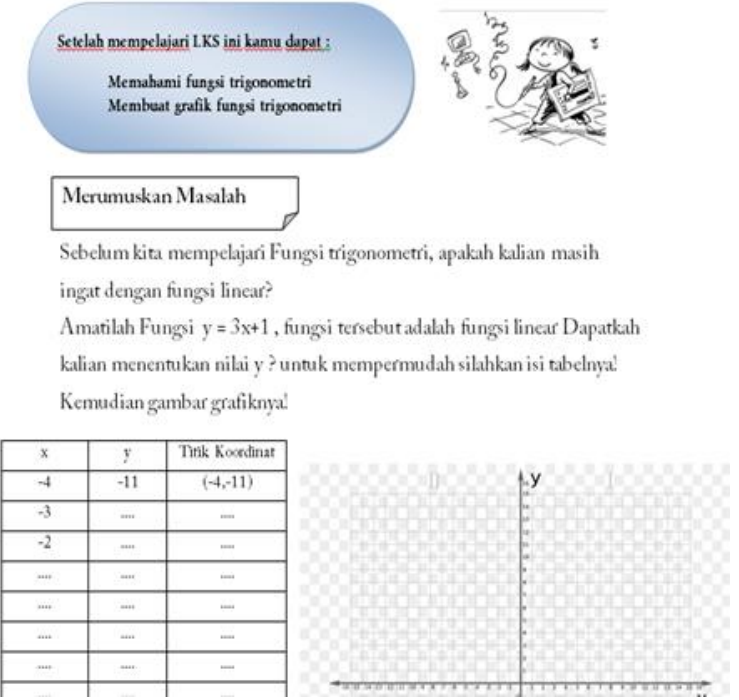

Gambar 4. LKS setelah revisi 
Berdasarkan masukan dari validator, LKS direvisi seperti terlihat pada Gambar 4. Siswa terlebih dahulu diberikan stimulus materi fungsi linear, setelah itu siswa mengkoneksikan dengan fungsi trigonometri. Dengan demikian diharapkan siswa dapat mengkonstruksi sendiri pengetahuan mengenai fungsi trigonometri. Setelah dilakukan revisi tehadap bahan ajar yang ditelah disusun berdasarkan masukan validator, kemudian bahan ajar diujicobakan kepada siswa kelas X sebanyak 6 pertemuan yaitu pertemuan pertama dengan materi perbandingan trigonometri pada segitiga sikusiku, pertemuan dua menemukan sifat-sifat dan hubungan antar perbandingan trigonometri, pertemuan tiga menentukan hubungan perbandingan trigonometri dari tiap kuadran, pertemuan empat perbandingan sudut berelasi, pertemuan kelima yaitu identitas trigonometri, serta pertemuan enam yaitu memahami konsep fungsi trigonometri dan menganalisis grafik fungsinya.

Setelah dilakukan uji coba bahan ajar berupa LKS sebanyak 6 pertemuan, LKS yang dikembangkan berupa kegiatan-kegiatan siswa dalam membangun konsep trigonometri dengan pendekatan inkuiri, terdapat uji kompetensi pada masing-masing pertemuan. Kemudian dilakukan tes akhir untuk menganalisis efektivitas LKS. Tes berupa soal HOTS materi trigonometri kepada 32 siswa pada subjek yang sama. Rekapitulasi hasil dari tes HOTS akhir disajikan pada Tabel 5.

Tabel 5. Rekapitulasi hasil tes HOTS akhir

\begin{tabular}{lccc}
\hline \multicolumn{1}{c}{ Aspek yang diukur } & SMI & $\overline{\boldsymbol{x}}$ & $\begin{array}{c}\text { \% ketercapaian } \\
\text { Indikator }\end{array}$ \\
\hline Berpikir Kritis & 25 & 17,6 & $70,4 \%$ \\
Berpikir Kreatif & 25 & 14,8 & $59,2 \%$ \\
Pemecahan Masalah & 25 & 15,8 & $63,2 \%$ \\
Membuat keputusan & 25 & 19,0 & $76 \%$ \\
Rata-rata & & 16,8 & $67,2 \%$ \\
\hline
\end{tabular}

Berdasarkan Tabel 5 terlihat bahwa rata-rata paling tinggi yaitu pada aspek membuat keputusan sebesar 16,8 dari SMI 25, sedangkan capaian paling rendah yaitu aspek berpikir kreatif sebesar 14, 8 namun dari keseluruhan kita dapat analisis pada persentase ketercapaian pada tes HOTS awal sebesar 31,9\%, sedangkan pada tes HOTS akhir sebesar $67,2 \%$, ini artinya terdapat peningkatan kemampuan HOTS siswa sebesar $35,3 \%$ setelah diberikan LKS trigonometri bebasis inkuiri sebanyak 6 pertemuan. Berdasarkan Tabel 2 efektivitas masuk kedalam kategori tinggi.

LKS berbasis inkuiri yang dikembangkan dapat meningkatkan HOTS siswa, proses berpikir menjadi terlatih dengan pendekatan inkuiri, langkah-langah inkuiri yaitu merumuskan masalah, menentukan hipotesis, mengumpulkan data, menarik kesimpulan serta melakukan generalisasi dapat melatih dalam mengembangkan cara berpikir yang ilmiah (Muakhirin, 2015; Sumarti et al., 2017; Tjiptiany et al., 2016). Pada tahap merumuskan masalah, siswa difokuskan untuk memahami masalah yang diberikan, dengan diawali masalah proses berpikir siswa menjadi lebih terlatih dari yang terbiasa disajikan rumus pada awal pembelajaran, pada LKS ini siswa justru dihadapkan pada masalah. Pada awal siswa merasa kesulitan dan belum terbiasa, namun dengan bimbingan yang diberikan oleh guru, siswa sudah terbiasa dengan masalah pada awal pembelajaran. Pada tahap menentukan hipotesis, siswa dituntut untuk membuat jawaban sementara dan bertanggung jawab untuk membuktikan hipotesis tersebut. Pada tahap pengumpulan data siswa diminta untuk menemukan data sebanyak-banyaknya yang dapat mendukung hipotesis yang telah dibuat kemudian siswa mengklasifikasikan dari banyaknya data mana yang diperlukan atau tidak. Pada tahap penarikan kesimpulan siswa membuat kesimpulan dari data-data yang telah diklasifikasikan kemudian kesimpulan yang dibuat digeneralisasikan pada kasus-kasus lain. Semua tahapantahapan pendekatan inkuiri pada LKS yang disusun dapat menumbuhkembangkan HOTS siswa secara signifikan. Bahan ajar yang dikembangkan dengan baik dapat meningkatkan kemampuan berpikir tingkat tinggi siswa (Adami et al., 2018; Sofyan, 2019), sehingga dapat memberikan dampak terhadap proses dan hasil belajar siswa (Zakiah \& Fajriadi, 2020).

Berdasarkan uraian di atas dapat kita cermati bahwa bahan ajar dapat dikembangkan guru sesuai dengan kebutuhan siswa. Keefektivan LKS berbasis inkuiri ini sesuai dengan hasil penelitian (Sumarti et al., 2017; Tjiptiany et al., 2016) bahwa bahan ajar yang dibuat bisa berupa LKS yang 
disusun secara klasikal atau individual, Peranan bahan ajar sangat penting dalam mencapai tujuan pembelajaran (Aisyi et al., 2013; Fitriani et al., 2020; Gazali, 2016; Kadarisma \& Ahmadi, 2019; Putri, 2017). LKS yang disusun dapat dikombinasikan dengan berbagai jenis pendekatan yang disesuaikan dengan karakter siswa serta analisis kesulitan terdahulu agar LKS yang digunakan dapat maksimal sehingga tujuan pembelajaran dapat tercapai dengan baik.

\section{KESIMPULAN}

Berdasarkan hasil dan pembahasan, kesimpulan dari penelitian ini adalah LKS berbasis inkuiri pada materi trigonometri yang telah dikembangkan dinyatakan valid dan efektif dalam meningkatkan HOTS siswa pada materi trigonometri, dengan rata-rata nilai validitas sebesar 3,4 serta efektivitas dari peningkatan kemampuan HOTS sebesar 35,3\%. Adapun implikasi dari penelitian ini yaitu guru dapat menggunakan LKS berbasis inkuiri ini sebagai bahan ajar pada materi trigonometri agar kemampuan HOTS siswa meningkat.

\section{REKOMENDASI}

Rekomendasi dari penelitian ini hendaknya peneliti yang akan melakukan penelitian pengembangan bahan ajar dengan desain 4D untuk melakukan tahap terakhir yaitu penyebaran agar bahan ajar yang dihasilkan lebih efektif

\section{UCAPAN TERIMAKASIH}

Terimakasih Kepada Kementrian Riset dan Teknologi / BRIN (Badan Riset dan Inovasi Nasional) yang telah mendanai penelitian ini. Serta LPPM IKIP Siliwangi yang telah banyak berkontribusi dalam memfasilitasi kegiatan penelitian ini..

\section{DAFTAR PUSTAKA}

Adami, M. A., Amali, P., \& Yurnetti. (2018). Bahan ajar beroientasi pemecahan masalah untuk mencapai HOTS. Pillar of Physics Education, 11(2), 17-24.

Ahmadi, Y., \& Kadarisma, G. (2020). Pelatihan menulis karya ilmiah bagi guru. Seminar Nasional REKARTA, 2-7.

Ahmatika, D. (2017). Peningkatan kemampuan berpikir kritis siswa dengan pendakatan inquiry/discovery. Euclid, 3(1), 394-403.

Aisyi, F. K., Elvyanti, S., Gunawan, T., \& Mulyana, E. (2013). Pengembangan bahan ajar TIK SMP mengacu pada pembelajaran berbasis proyek. INVOTEC, IX(2), 117-128.

Anderson, L., \& Krathwohl, D. R. (2015). Kerangka landasan untuk pembelajaran, pengajaran, dan asesmen: revisi taksonomi pendidikan bloom. Pustaka Pelajar.

Dila, O. R., \& Zanthy, L. S. (2020). Identifikasi kesulitan siswa dalam menyelesaikan soal aritmatika sosial. Teorema: Teori dan Riset Matematika, 5(1), 17-26.

Dinni, H. N. (2018). HOTS (high order thinking skills) dan kaitannya dengan kemampuan literasi matematika. Prisma, 1, 170-176.

Fatimah, A. T., \& Zakiah, N. E. (2018). Kelancaran prosedural matematis dalam pemecahan masalah konteks pemasaran. Mathline, 3, 141-150.

Fitriani, N., Kadarisma, G., \& Amelia, R. (2020). Pengembangan desain didaktis untuk mengatasi 
learning obstacle pada materi dimensi tiga. Aksioma: Jurnal Matematika dan Pendidikan Matematika UPGRIS Semarang, 9(2), 231-241.

Gazali, R. Y. (2016). Pengembangan bahan ajar matematika untuk siswa smp berdasarkan teori belajar ausubel. 11, 182-192.

Hadi, S., \& Novaliyosi. (2019). TIMSS Indonesia (Trends in International mathematics and science study). Prosiding Seminar Nasional \& Call for Papers Program Studi Magister Pendidikan Matematika Universitas Siliwangi, 562-569.

Jusniani, N. (2016). Pendekatan inkuiri dalam pembelajaran matematika untuk meningkatkan kemampuan berpikir kritis siswa smp kelas vii. Seminar Nasional Matematika dan Pendidikan Matematika, 119-126.

Kadarisma, G. (2016). Improving students' logical thinking mathematic skill through learning cycle 5e and discovery learning. Proceeding of 3rd International Conference on Research Implementation Education of Mathematics and Science.

Kadarisma, G., \& Ahmadi, Y. (2019). Pelatihan penggunaan media pembelajaran berbasis ict kepada guru sekolah dasar. Amal Ilmiah: Jurnal Pengabdian Kepada Masyarakat, 1(1), 35-40.

Kadarisma, G., Senjayawati, E., \& Amelia, R. (2019). Pedagogical content knowledge pre-service mathematics teacher. Journal of Physics: Conference Series, 1315(1).

Kristianingsih, D. D., \& Wijayati, N. (2016). Education pengembangan Iks fisika bermuatan generik sains untuk meningkatkan higher order thinking (HOTS) siswa. Journal of Innovative Science, 5(1), 73-82.

Mahendratama, F. J. (2019). Analisis kemampuan siswa sma dalam menyelesaikan soal hots materi trigonometri ditinjau dari gaya belajar. Prosiding SEMDIKJAR (Seminar Nasional Pendidikan dan Pembelajaran), 5(2), 123-131.

Muakhirin, B. (2015). Peningkatan hasil belajar ipa melalui pendekatan pembelajaran inkuiri pada siswa sd. Jurnal IImiah Guru Caraka Olah Pikir Edukatif, 1(18).

Mulbasari, A. (2016). Bahan ajar berbasis inquiry untuk mendorong aktivitas berpikir kritis matematika siswa. Prosiding Seminar Nasional Pendidikan, 1(1), 187-198.

Musfiqi, S., \& Jailani. (2014). Pengembangan bahan ajar matematika yang berorientasi pada karakter dan higher order thinking skill (hots). Pythagoras: Jurnal Pendidikan Matematika, 9(1), 45-59.

Perdani, H. N., \& Azka, R. (2019). Teknologi dan pembelajaran matematika generasi milenial. Proseding Sendika, 5(1), 508-514.

Putri, Y. B. (2017). Pengembangan bahan ajar berbasis alqurun teaching model (atm) pada materi teorema pythagoras. Universitas Bandar Lampung.

Resnick, L. (1987). Education and learning to think. National Academy Press. 
Saputra, H. (2016). Pengembangan mutu pendidikan menuju era global: Penguatan mutu pembelajaran dengan penerapan hots (high order thinking skills). SMILE's Publishing.

Sariningsih, R., \& Kadarisma, G. (2017). Meningkatkan kemampuan berpikir kreatif matematis dan kemandirian belajar siswa smp melalui pendekatan saintifik berbasis etnomatematika. P2M STKIP Siliwangi, 3(1), 53-56.

Sofyan, F. A. (2019). Implementasi hots pada kurikulum 2013. Inventa, 3(1), 1-9.

Sudjana, N. (2008). Dasar-dasar proses belajar mengajar. Sinar Baru Algesido.

Sumarti, S., Rahayu, Y. S., \& Madlazim, M. (2017). Pengembangan perangkat pembelajaran berbasis inkuiri terbimbing untuk melatih literasi sains siswa. JPPS (Jurnal Penelitian Pendidikan Sains), 5(1), 822.

Susanto, E., \& Retnawati, H. (2016). Perangkat pembelajaran matematika bercirikan pbl untuk mengembangkan hots siswa SMA. Jurnal Riset Pendidikan Matematika, 3(2), 189.

Tjiptiany, E., As'ari, A., \& Muksar, M. (2016). Pengembangan modul pembelajaran matematika dengan pendekatan inkuiri untuk membantu siswa sma kelas $\mathrm{x}$ dalam memahami materi peluang. Jurnal Pendidikan-Teori, Penelitian, dan Pengembangan, 1(10), 1938-1942.

Utari, T., Hobri, \& Oktavianingtyas, E. (2017). Pengembangan lembar kerja siswa (Iks) matematika berorientasi scientific approach untuk menumbuhkan kemampuan higher order thinking (hot) pokok bahasan persamaan lingkaran pada siswa sma kelas xi. Kadikma, 8(2), 13-23.

Wardhani, I., Hobri, \& Oktavianingtyas, E. (2017). Pengembangan lembar kerja siswa matematika berorientasi scientific approach untuk menumbuhkembangkan kemampuan hot pokok bahasan trigonometri pada siswa sma kelas x. Kadikma, 8(2), 1-12.

Yenni, Y., \& Sukmawati, R. (2019). Analisis kemampuan berpikir reflektif matematis berdasarkan minat belajar pada mata kuliah struktur aljabar. Teorema: Teori dan Riset Matematika, 4(2), 75-82.

Zakiah, N. E. (2016). Meningkatkan kemampuan metakognitif siswa melalui pembelajaran dengan pendekatan open-ended. Teorema: Teori dan Riset Matematika, 1(1).

Zakiah, N. E., \& Fajriadi, D. (2020). Hybrid-PjBL: Creative thinking skills and self-regulated learning of preservice Teachers. J. Phys.: Conf. Ser. 1521032072. 